\title{
Development of a Model to Investigate Factors influencing Utilisation of Research4Life Databases by Agricultural Researchers in Nigeria
}

\author{
Luke O. Obasuyi ${ }^{1 *}$, Okwilagwe $\mathrm{OA}^{2}$ \\ ${ }^{T}$ John Harris Library, University of Benin, P.M.B. 1154, Benin City, Nigeria \\ ${ }^{2}$ John Harris Library, University of Benin, P.M.B. 1154, Benin City, Edo State, Nigeria \\ ${ }^{2}$ Department of Library, Archival and Information studies University of Ibadan, P.M.B. 1, UI, Ibadan Nigeria
}

*Corresponding Author

Dr. Luke Osamudiamen Obasuyi

\author{
Article History \\ Received: 24.06.2020 \\ Accepted: 01.07.2020 \\ Published: 16.07.2020
}

\begin{abstract}
This study is part of a doctoral thesis aimed at developing and validating a theoretical-based model to investigate factors influencing utilisation of Research4Life databases in National Agricultural Research Institutes (NARIs) in Nigeria. Research4Life databases are underutilised in the NARIs in spite of their importance in agricultural research. To enhance their utilisation, an appropriate model was required. This study developed and validated the Utilisation of Research4Life Database Model (URDM) made up of 22 independent constructs. Some constructs from Diffusion of Innovation; Technology Acceptance Model; Unified Theory of Acceptance and Use of Technology, and Technology, Organisation and Environmental models were adopted and others introduced to develop the model. To validate the model, the study adopted the descriptive survey design of the correlational type. Simple and stratified random sampling techniques were used to select $744(62 \%)$ scientists from a population of 1,205. A validated and pretested questionnaire consisting of 105 questions arranged in five sections A - E with 0.99 reliability coefficient based on Cronbach alpha method was used for data collection. Simple percentage, mean, correlation, multiple regression and analysis of variance were used to analyse the data. All the 23 formulated hypotheses were significant. The 22 independent factors showed direct positive relationship with utilisation of the databases. Overall, the URDM accounted for $67 \%$ level of utilisation of Research4Life databases in NARIs. Thus, the model is adequate for investigating factors influencing utilisation of Research4Life databases in Nigeria. The findings of this study contributed to the literature by validating the URDM in NARIs in Nigeria.
\end{abstract}

Keywords: Utilisation model, Research4Life databases, Individual factors, Institutional factors, System factors.

\section{INTRODUCTION}

Research4Life is the collective name for five databases: HINARI-Health Internetwork Access to Research Initiative, AGORA - Access to Global Online Research in Agriculture, OARE - Online Access to Research in the Environment, ARDI-Access to Research for Development and Innovation, and GOALI-Research for Global Justice that provides developing countries with either low cost access to over 100,400 online academic and professional peerreviewed journals and e-books in the fields of health, agriculture, environment, applied sciences and legal information to meet researchers information needs in both developed and developing countries including Nigeria [1]. Journal articles in Research4Life databases have been used to support research activities in many universities, colleges, research institutes, to reduce the North and South information divide, enhance the quality of agricultural research and manuscripts rejection among African scientists [2].

Utilisation of Research4Life databases have impacted positively on research productivity of agricultural scientists in institutions where the databases have been successfully implemented and used. Due to the immense benefits derived from using these databases, NARIs scientists have been using them to enhance their research productivity. However, utilisation of Research4Life databases by NARIs scientists is low [3]. It therefore becomes necessary to investigate the factors that will influence utilisation of the databases in NARIs. To achieve this objective, an appropriate

Copyright @ 2020: This is an open-access article distributed under the terms of the Creative Commons Attribution license which permits unrestricted use, distribution, and reproduction in any medium for non commercial use (NonCommercial, or CC-BY-NC) provided the original author and source are credited. 
model becomes imperative. The aim of this study therefore, is to develop and validate a theoretical-based model to investigate factors influencing utilisation of Research4Life databases in NARls in Nigeria.

There are various factors influencing utilisation of Information Technology (IT) including Research4Life databases. Twenty two (22) of such factors have been identified for investigation in this study and they are classified into individual (intention to use, task at hand, computer anxiety, prior ICT experience, ICT searching skills, and computer/Internet self-efficacy), institutional (accessibility of databases, availability of password, fast Internet access, adequate training and infrastructures, help and technical support services) and system (availability of full-text articles, quality of databases content, currency of databases content, free download of articles, availability of local journal content, databases design features, quick access to journal articles, compatibility, perceived ease of use and perceived usefulness) factors and they are discussed below.

Behavioural intention has been seen to influence the actual and perceived utilisation of various IT in many studies. Davis [4] and Venkatesh, Morris, Davis and Davis [5] posit that behavioural intention to use a given technology has significant influence on usage behaviour. Dulle and Minishi-Majanja [6] found that behavioural intention influenced researchers' actual use of open access in Tanzania while Angello [7] opined that individual factors determine the acceptance and utilisation of Research4Life databases among agricultural researchers in Tanzania. It is therefore hypothesised that:

H1: There is a significant positive influence of behavioural intention on utilisation of Research4Life databases by NARIs scientists in Nigeria.

Task at hand is another factor capable of influencing utilisation of Research4Life databases. When a scientist develops intention to use IS, the intention is put into action by the task he or she performs thereafter. Igbeka and Atinmo [8] found that task performed by agricultural researchers influenced their information use resulting in a significant difference in their information behaviour. Wang and $\mathrm{Wu}$ [9] posit that task affect use and non-use of Internet ICT in the US and China among researchers. It is therefore hypothesised that:

$\mathrm{H} 2$ : There is a significant positive influence of task performed on utilisation of Research4Life databases by NARIs scientists in Nigeria.

Computer anxiety is a major factor that influences system success in IS research [10]. To use Research4Life databases effectively, the level of computer anxiety of the scientists is very important because the databases are online and computers are required to use them. Venkatesh and Bala [11] findings indicated that computer anxiety significantly predict perceived ease of use of IT. Nov and Ye [12] equally found that computer anxiety predicted perceived ease of use and utilisation of digital libraries in North-eastern United State of America. It is therefore hypothesised that:

H3: There is a significant positive influence of computer anxiety on utilisation of Research4Life databases by NARIs scientists in Nigeria.

Prior ICT experience could influence utilisation of Research4Life databases. Crespo, Sanchez and Bosque [13] showed that prior ICT experience moderated utilisation of e-commerce while Lee and Coughlin [14] found that older adults' decision to use ICT is affected by past ICT experience. Abramson, Dawson and Stevens [15] found a relationship between prior use of e-learning and intention to use M-learning. In Nigeria, Adeyinka [16] revealed that prior knowledge of ICT significantly correlates with librarian use of IT in Oyo State. It is therefore hypothesised that:

H4: There is a significant positive influence of prior ICT experience on utilisation of Research4Life databases by NARIs scientists in Nigeria.

Information and Communication Technology (ICT) searching skills are important factors that could influence utilisation of Research4Life databases. Muinde and Gorman [17] reported that researchers in agricultural research institutes in Kenya searching skills affected their use of IT. Parker [18] averred that training on how to search Research4Life databases affected their use to make informed decisions. It is therefore hypothesised that:

H5: There is a significant positive influence of ICT searching skills on utilisation of Research4Life databases by NARIs scientists in Nigeria.

Computer and Internet self-efficacy are needed to use Research4Life databases. Computer and Internet selfefficacy is a measure of NARIs scientists' confidence in their ability to use the computer and Internet. Dulle, Minishmajanja and Cloete [6] revealed that computer and Internet self-efficacy significantly influenced intention and use of open access in Tanzanian. Akinbobola and Adeleke [19] and Odede [20] found that computer self-efficacy has a positive influence on actual and intention to use the KOHA system and online information resources in Nigeria respectively. 
Nwobu, Oyewole and Apotiade [21] concluded that there was a significant positive relationship between computer selfefficacy and use of OPAC. Based on the foregoing, it is therefore hypothesised that:

H6: There is a significant positive influence of computer and Internet self-efficacy on utilisation of Research4Life databases by NARIs scientists in Nigeria.

Accessibility of databases is a crucial institutional factor that may influence utilisation of Research4Life databases. Accessibility refers to the degree of ease with which users can access and use a technology [22]. ITOCA [3] identified accessibility as a major problem affecting utilisation of Research4Life databases in developing countries. This trend is gradually changing as ITOCA [23] concluded that accessibility to Reaserch4Life has improved. At the Michael Okpara University of Agriculture Umudike, Nigeria, Uzuegbu and McAlbert [24] averred that students and lecturers have access to Research4Life databases thus enhancing their use. Based on the foregoing evidence, it is therefore hypothesised that:

H7: There is a significant positive influence of database accessibility on utilisation of Research4Life databases by NARIs scientists in Nigeria.

Availability of password is another factor that could influence utilisation of Research4Life databases. Salaam [25] opined that researchers tend to overlook the usage of AGORA database because password is required to access it. Alison, Kiyingi and Baziraake [26] further reported that HINARI has a complex password limiting access and usage of the database. Constant availability of password may positively influence access and utilisation of Research4Life databases in NARIs. Uzuegbu and McAlbert [24] reported that availability of passwords influenced the use of Research4Life databases in their universiy in Nigeria. Based on the foregoing, it is therefore hypothesised that:

H8: There is a significant positive influence of availability of password on utilisation of Research4Life databases by NARIs scientists in Nigeria

Fast Internet access is required for effective utilisation of Research4Life databases. Rhoe, Oboh and Shelton [27] study of libraries supporting agriculture in Nigeria revealed that low bandwidth was a critical factor in all the libraries. Ogunjobi and Fagbami [28] also identified slow Internet speed occasioned by low bandwidth as the most critical factor hindering the use of Internet in research institutes in Oyo State, Nigeria. However, this situation is gradually improving in some African countries as ITOCA [29] survey indicated improved connectivity. Based on the foregoing, it is therefore hypothesised that:

H9: There is a significant positive influence of computer and Internet self-efficacy on utilisation of Research4Life databases by NARIs scientists in Nigeria.

Adequate training is a factor that may predict the use of Research4Life databases. Training is the systematic modification of behaviour through learning, education, instruction, and experience. Lakan [30] recommended adequate training in ICT for scientists in the research institutes in Nigeria to use digital resources. Chimwaza and Chimalizeni [31] reported that ITOCA has delivered 80 short courses to address knowledge and skill gaps to use Research4Life databases in the last 12 years. Therefore, adequate training could influence NARIs scientists to use Research4Life databases. It is therefore hypothesised that:

H10: There is a significant positive influence of adequate training on utilisation of Research4Life databases by NARIs scientists in Nigeria.

Adequate ICT infrastructure could influence utilisation of Research4Life databases. ITOCA [23] found low einformation usage due to low infrastructure in seven institutions in Africa. Mtega, Dulle, Malekani and Chailla [32] found low usage of Research4Life databases among agricultural researchers in Tanzania due to inadequate ICT infrastructure. In Nigeria, Rhoe, Oboh and Shelton [27] reported that limited ICT infrastructure was the primary factors for faculty and students not using Research4Life databases in Nigerian libraries. Therefore, provision of adequate infrastructures could influence Research4Life databases utilisation among NARIs scientists in Nigeria. It is hypothesised that:

H11: There is a significant positive influence of adequate ICT infrastructure on utilisation of Research4Life databases by NARIs scientists in Nigeria. 
Help and technical support services are factors that may influence utilisation of Research4Life databases. Help and technical support services are the extent to which an individual believes that human and infrastructure exist to support the use of the system. Chang [33] found a positive relationship between facilitating condition and actual use of Intranet at the University of North Carolina. In addition, Seymour, Allen and Duma [34] found that facilitating conditions directly affect the use of ER portal system at Murdoch University, Australia. Abbad, Morris and de Nahlik [35] revealed that perception of the level of technical support available to users have a direct effect on utilisation of the technology. Availability of help and technical support services may have a positive effect on utilisation of Research4Life databases. Based on the foregoing, it is therefore hypothesised that:

H12: There is a significant positive influence of help/technical support services on utilisation of Research4Life databases by NARIs scientists in Nigeria.

Availability of full-text journal articles in Research4Life databases is the major benefit expected to be derived by NARIs scientists from using the databases. Wood [36] opined that full-text journal articles indexed in MEDLINE enhanced access and usage of HINARI. Gaible, Gedye, Ochs, Parker and Rudgard [37] posit that assessing full-text articles was the major challenge to use Research4Life databases in developing countries. In Osun State, Nigeria, Shabi, Shabi, Akewukereke and Udofia [38] concluded that availability of full-text evidence based resources is a major determinant of utilising PubMed, HINARI and other medical database. Availability of full text articles may positively influence utilisation of the Research4Life databases. Based on the foregoing, it is therefore hypothesised that:

H13: There is a significant positive influence of availability of full-text articles on utilisation of Research4Life databases by NARIs scientists in Nigeria.

Quality of database content is a factor that may influence utilisation of Research4Life databases and scientists need peer reviewed articles for their research work which they expect to get from the databases. Miller and Khera [39] revealed that trust in content influenced utilisation of the digital library by researchers in Kenya and Peru. Tao [40] also found that information and system quality both impacted actual use of e-resources. Paj and Huang [41] concluded that information quality and system quality influence users' intention to use healthcare information system. Content quality of Research4Life databases may positively influence the use of the databases. Based on the foregoing, it is therefore hypothesised that:

H14: There is a significant positive influence of quality of database content on utilisation of Research4Life databases by NARIs scientists in Nigeria.

Currency of databases information content is a factor that could influence utilisation of Research4Life databases. An article is current if it is published in the last five years and it has been used to judge the quality of scientific publications. ITOCA [23] survey in seven African countries indicated high demand for current research materials from Research4Life databases. In Zimbabwe, Malapela and Jager [42] posit that agricultural scientists depend on current articles in Research4Life databases to obtain recent information for their own research. Therefore, the currency of information in Research4Life databases may have a positive effect on their utilisation. From the above analysis, it is therefore hypothesised that:

H15: There is a significant positive influence of the currency of database information content on utilisation of Research4Life databases by NARIs scientists in Nigeria.

Free download of journal articles is capable of influencing utilisation of Research4Life databases. The concept of Research4Life databases is to provide access to free or low cost information resources from donor publishers. However, Parker [18] submitted that not all articles in Research4Life databases are freely downloaded and it can affect usage. Davis and Walters [43] confirmed that there is clear evidence that free access increase the number of article downloads in Research4Life databases. Free download of journal articles will create more activities at the databases sites which in turn may influence utilisation of Research4Life databases in Nigeria. Based on the foregoing, it is therefore hypothesised that:

H16: There is a significant positive influence of free download of journal articles on utilisation of Research4Life databases by NARIs scientists in Nigeria.

Availability of local content is capable of influencing utilisation of Research4Life databases. Parker [18] posits that the content of articles in Research4Life databases is highly controlled. However, most of the articles in Research4Life databases are published outside Africa. Bringula and Basa [44] found that the kind of information content as a web portal design-related factor was the only significant predictor of web portal usability. Lowga et al., [45] indicated the need to incorporate more local journals from developing world into TEEAL and Research4Life databases. Chimwaza and Chimalizeni [31] reported improved access to local and international content in TEEAL, AGORA and 
HINARI. Adequate access to local content may be a significant motivation to use Research4Life databases in NARIs. Based on the foregoing, it is therefore hypothesised that:

H17: There is a significant positive influence of availability of local journal content on utilisation of Research4Life databases by NARIs scientists in Nigeria.

Database design features are system factors that can influence utilisation of IS and Research4Life databases [4]. They are broadly categorised into information and system related factors. Ahn, Ryu and Han [45] found that web quality (system and information design factors) had a significant impact on website utilisation in the online retailing context in Korea. Venkatesh and Bala [11] averred that information-related factors of a system will influence perceived usefulness while system-related factors will influence perceived ease of use. Tao [40] found that information and system quality influenced actual use of e-resources. Thus, database design features may influence utilisation of Research4Life databases in NARIs. From the foregoing, it can be hypothesised that:

H18: There is a significant positive influence of database design features on utilisation of Research4Life databases by NARIs scientists in Nigeria.

Quick access to journal articles is a system factors that could influence utilisation of Research4Life databases. When information is difficult to access due to complexity in the system design, users tend to abandon it even though it may be very useful. Thanuskodi [46] listed slow Internet speed, long time to view and download web pages as problems faced by agricultural students in surfing the web. In Nigeria, Salaam [25] observed that researchers tend to overlook AGORA database because it takes much time to access while Rhoe, Oboh and Shelton [27] found difficulties accessing journal articles in Research4Life databases. Quick access to journal articles may influence NARIs using Research4Life databases in Nigeria. From the foregoing, it can be hypothesised that:

H19: There is a significant positive influence of database design features on utilisation of Research4Life databases by NARIs scientists in Nigeria.

Compatibility is DOI external factor expected to influence utilisation of Research4Life databases. Chau and $\mathrm{Hu}$ [47] argued that compatibility is an external variable in TAM that affects perceived usefulness, perceived ease of use and utilisation of databases. Wu and Wang [48] findings indicated that compatibility has the most important effect on behavioural intention to use and actual use of mobile commerce in Taiwan. Crespo, Sanchez and Bosque [13] support that compatibility has a positive influence on attitudes, perceived usefulness and perceived ease of use of e-commerce. From the foregoing, it can be hypothesised that:

H20: There is a significant positive influence of compatibility on utilisation of Research4Life databases by NARIs scientists in Nigeria.

Perceived ease of use is a system related factor that could enhance usage of e-resources in scientific research. It exerts its influence directly or indirectly on utilisation of the technology. Using the TAM, Brown [49] confirmed that perceived ease of use influence utilisation of IT in developing countries. Nov and Ye [12] indicated that perceived ease of use was a significant determinant of digital libraries utilisation of a university digital library in North-eastern United State of America. Miller and Khera [39] found that perceived ease of use of the TEEAL system, was a major predictor of intent to utilise the system by agricultural researchers in Kenya and Peru. From the foregoing, it can be hypothesised that:

H21: There is a significant positive influence of perceived ease of use on utilisation of Research4Life databases by NARIs scientists in Nigeria.

Perceived usefulness is a major factor influencing utilisation of IT and IS. TAM emphasised perceived usefulness as the key determinant of user acceptance of a technology [4]. Wu and Wang [9] indicated that user acceptance of mobile commerce in Taiwan can be predicted by intentions and perceived usefulness. Korobili, Tilikidou and Delistavrou [50] found that perceived usefulness influence faculty members to utilise library e-resources in Greece. Tao [40] also found that perceived usefulness had significant impact on both intention and actual usage of e-resources in the U.S. In Nigeria, Therefore, perceived usefulness will positively influence utilisation of Research4Life databases. From the foregoing, it can be hypothesised that:

H22: There is a significant positive influence of perceived usefulness on utilisation of Research4Life databases by NARIs scientists in Nigeria. 


\section{ReSEARCh Model}

The model proposed in this study is based on Diffusion of Innovation (DOI) Rogers [51]; Technology Acceptance Model (TAM) Davis [4]; Unified Theory of Acceptance and Use of Technology (UTAUT) Venkatesh et al. [11] and Technology, Organisation and Environmental (TOE) framework [52] models. Many empirical studies integrated two or more models in IS research to improve the capacity to explore a broad spectrum of factors influencing IT utilisation $[53,54]$. Therefore, adapting four models to investigate factors influencing utilisation of Research4Life databases in Nigeria is therefore adequate.

Twelve (12) constructs: intention to use, perceived usefulness, perceived ease of use, relative advantage, complexity, compatibility, performance expectancy and effort expectancy and facilitating conditions, help and technical support services, adequate ICT infrastructure and database design features were selected from the four models which were added to individual (task at hand, computer anxiety, ICT searching skills, Prior IT experience, computer and Internet self-efficacy), institutional (database accessibility, availability of password, fast Internet access, adequate training, and) and system (availability of full text articles, quality of databases, currency of content, free download of journal articles, availability of local journal content, and quick access to journal articles) factors to build the study's model. In this study, there are two sets of variables: the dependent and independent variables. Utilisation of Research4Life databases is the dependent variable while the independent variables are the 22 factors under investigation. The dependent variable is influenced directly by a set of independent variables. These factors could individually and collectively predict utilisation of Research4Life databases by NARIs in Nigeria.

\section{Methodology}

This study adopted the descriptive survey research design of the correlational type. The study population consists of 1,205 research scientists in the 15 NARIs. Simple random and stratified random sampling techniques were used to select 13 of the 15 NARIs and 744 research scientists which is $62 \%$ of the total population of scientists in NARIs respectively. The questionnaire was the instrument used and it consists of 105 questions arranged in five sections A - E. Section A dwelt on demographic information; section B on individual factors; section C centered on institutional factors while section D addressed the system factors. Section E covered the dependent factors which is utilisation of Research4Life databases. The questionnaire adopted the four point likert scale technique for answering questions. Each degree of agreement or disagreement is given a numerical value from four to one (strongly agree (4), agree (3), disagree (2) and strongly disagree (1). For the weighted means to be significant, the decision rule was based on the mean being more than or up to 2.5. The questionnaire was assessed for face and content validity by five experts and pre-tested using 30 lecturers in the Faculty of Agriculture, University of Benin, Benin City. The reliability of the questionnaire was assessed using the Cronbach Coefficient Alpha method. The reliability coefficient for the whole questionnaire was 0.99 alpha while the values for individual, institutional and system factors were 0.97 alpha, 0.97 alpha and 0.94 alpha respectively and utilisation was 0.96 . Simple percentage, mean, correlation, multiple regression and analysis of variance were used to analyse the data using SPSS 17.0.

\section{Results of AnAlyseS}

\section{Testing of Hypotheses 1 - 6 (Individual factors)}

Six individual factors were tested in this study. Result in Table 1 shows that there were significant relationships between intention to use, $\left(\beta=.519^{* *}, \mathrm{P}(.000)<.05\right)$, task at hand, $\left(\beta=.567^{* *}, \mathrm{P}(.000)<.05\right)$, computer anxiety, $(\beta=$ $\left..651^{* *}, \mathrm{P}(.000)<.05\right)$, prior ICT experience, $\left(\beta=.613^{* *}, \mathrm{P}(.000)<.05\right)$, ICT searching skills, $(\beta=.629 * *, \mathrm{P}(.000)<.05)$, computer/Internet self-efficacy, $\left(\beta=.644^{* *}, \mathrm{P}(.000)<.05\right)$ and utilisation of Research4Life databases. The hypotheses were therefore accepted. The result also showed a strong correlation between individual factors and utilisation of Research4Life databases as their correlation value range from 0.519 to 0.651 . These results implied that all the individual factors were significant and thus influence utilisation of Research4Life databases by scientists in NARIs. 
Table-1: Correlation matrix showing the significant relationships between Individual factors and Utilisation of Research4Life databases by NARIs scientists in Nigeria

\begin{tabular}{|c|c|c|c|c|c|c|c|c|c|}
\hline & $\begin{array}{l}\text { Utilisation of } \\
\text { Research4Life }\end{array}$ & $\begin{array}{l}\text { Intention } \\
\text { to use }\end{array}$ & $\begin{array}{l}\text { Task at } \\
\text { hand }\end{array}$ & $\begin{array}{l}\text { Computer } \\
\text { Anxiety }\end{array}$ & $\begin{array}{l}\text { Prior ICT } \\
\text { Experience }\end{array}$ & $\begin{array}{l}\text { ICT } \\
\text { Searching } \\
\text { Skills } \\
\end{array}$ & $\begin{array}{l}\text { Computer/ } \\
\text { Internet Self } \\
\text { Efficacy }\end{array}$ & Mean & S.D \\
\hline $\begin{array}{l}\text { Utilisation of } \\
\text { Research4Life }\end{array}$ & 1 & & & & & & & 34.16 & 19.07 \\
\hline Intention to use & $\begin{array}{l}.519 * * \\
.000\end{array}$ & 1 & & & & & & 28.95 & 14.85 \\
\hline Task at hand & $\begin{array}{l}.567 * * \\
.000 \\
\end{array}$ & $\begin{array}{l}.805 * * \\
.000\end{array}$ & 1 & & & & & 26.45 & 12.84 \\
\hline $\begin{array}{l}\text { Computer } \\
\text { Anxiety }\end{array}$ & $\begin{array}{l}.651 * * \\
.000\end{array}$ & $\begin{array}{l}.659 * * \\
.000\end{array}$ & $\begin{array}{l}.772 * * \\
.000\end{array}$ & 1 & & & & 30.59 & 15.28 \\
\hline $\begin{array}{l}\text { Prior ICT } \\
\text { Experience }\end{array}$ & $\begin{array}{l}.613 * * \\
.000 \\
\end{array}$ & $\begin{array}{l}.726 * * \\
.000 \\
\end{array}$ & $\begin{array}{l}.757 * * \\
.000 \\
\end{array}$ & $\begin{array}{l}.829 * * \\
.000 \\
\end{array}$ & 1 & & & 25.81 & 12.89 \\
\hline $\begin{array}{l}\text { ICT Searching } \\
\text { Skills }\end{array}$ & $\begin{array}{l}.629 * * \\
.000 \\
\end{array}$ & $\begin{array}{l}.688^{*} \\
.000 \\
\end{array}$ & $\begin{array}{l}.718 * * \\
.000\end{array}$ & $\begin{array}{l}.782 * * \\
.000\end{array}$ & $\begin{array}{l}.864 * * \\
.000 \\
\end{array}$ & 1 & & 25.93 & 13.58 \\
\hline $\begin{array}{l}\text { Computer/ } \\
\text { Internet Self } \\
\text { Efficacy }\end{array}$ & $\begin{array}{l}.644 * * \\
.000\end{array}$ & $\begin{array}{l}.719 * * \\
.000\end{array}$ & $\begin{array}{l}.735^{* * *} \\
.000\end{array}$ & $\begin{array}{l}.767 * * \\
.000\end{array}$ & $\begin{array}{l}.497 * * \\
.000\end{array}$ & $\begin{array}{l}.878^{* *} \\
.000\end{array}$ & 1 & 27.11 & 14.28 \\
\hline
\end{tabular}

\section{Testing of Hypotheses 7 - 12 (Institutional factors)}

Six institutional factors were tested in this study. Results in Table 2 showed that there were significant relationships between accessibility, $\left(\beta=.718^{* *}, \mathrm{P}(.000)<.05\right)$, availability of password, $\left(\beta=.684^{* *}, \mathrm{P}(.000)<.05\right)$, fast Internet access, $(\beta=.684 * *, \mathrm{P}(.000)<.05)$, adequate training, $(\beta=.652 * *, \mathrm{P}(.000)<.05)$, adequate ICT infrastructure, $\left(\beta=.643^{* *}, \mathrm{P}(.000)<.05\right)$, help/technical support services, $\left(\beta=.663^{* *}, \mathrm{P}(.000)<.05\right)$ and utilisation of Research4life databases. The hypotheses were therefore accepted. The result also showed a strong correlation between the institutional factors and utilisation of Research4Life databases as their correlation value range from 0.643 to 0.718 . The result implied that all the institutional factors were significant and influenced the utilisation of Research4Life databases by NARIs scientists in Nigeria.

Table-2: Correlation matrix showing the significant relationships between Institutional factors and Utilisation of Research4Life databases by NARIs scientists in Nigeria

\begin{tabular}{|c|c|c|c|c|c|c|c|c|c|}
\hline & $\begin{array}{l}\text { Utilisation of } \\
\text { Research4life }\end{array}$ & Accessibility & $\begin{array}{l}\text { Availability } \\
\text { of } \\
\text { Password } \\
\end{array}$ & $\begin{array}{l}\text { Fast } \\
\text { Internet } \\
\text { Access } \\
\end{array}$ & $\begin{array}{l}\text { Adequate } \\
\text { Training }\end{array}$ & $\begin{array}{l}\text { Adequate ICT } \\
\text { Infrastructure }\end{array}$ & $\begin{array}{l}\text { Help/Te } \\
\text { chnical } \\
\text { Support }\end{array}$ & Mean & S.D \\
\hline $\begin{array}{l}\text { Utilisation of } \\
\text { Research4life } \\
\text { Databases }\end{array}$ & 1 & & & & & & & 34.16 & 19.07 \\
\hline Accessibility & $\begin{array}{l}.718 * * \\
.000\end{array}$ & 1 & & & & & & 26.54 & 13.09 \\
\hline $\begin{array}{l}\text { Availability } \\
\text { of Password }\end{array}$ & $\begin{array}{l}.684 * * \\
.000\end{array}$ & $\begin{array}{l}.841^{* *} \\
.000\end{array}$ & 1 & & & & & 22.68 & 12.03 \\
\hline $\begin{array}{l}\text { Fast Internet } \\
\text { Access }\end{array}$ & $\begin{array}{l}.684 * * \\
.000\end{array}$ & $\begin{array}{l}.843 * * \\
.00\end{array}$ & $\begin{array}{l}.764 * * \\
.000\end{array}$ & 1 & & & & 26.19 & 13.59 \\
\hline $\begin{array}{l}\text { Adequate } \\
\text { Training }\end{array}$ & $\begin{array}{l}.652 * * \\
.000\end{array}$ & $\begin{array}{l}.817 * * \\
.000\end{array}$ & $\begin{array}{l}.721^{* *} \\
.000\end{array}$ & $\begin{array}{l}.917 * * \\
.000\end{array}$ & 1 & & & 26.36 & 13.96 \\
\hline $\begin{array}{l}\text { Adequate ICT } \\
\text { Infrastructure }\end{array}$ & $\begin{array}{l}.643^{* * *} \\
.000\end{array}$ & $\begin{array}{l}.739 * * \\
.000\end{array}$ & $\begin{array}{l}.688 * * \\
.000\end{array}$ & $\begin{array}{l}.797 * * \\
.000\end{array}$ & $\begin{array}{l}.848^{* *} \\
.000\end{array}$ & 1 & & 23.23 & 12.61 \\
\hline $\begin{array}{l}\text { Help/Technic } \\
\text { al Support }\end{array}$ & $\begin{array}{l}.663 * * \\
.000\end{array}$ & $\begin{array}{l}.840 * * \\
.000\end{array}$ & $\begin{array}{l}.731 * * \\
.000\end{array}$ & $\begin{array}{l}.848^{* *} \\
.000\end{array}$ & $\begin{array}{l}.875^{* *} \\
.000\end{array}$ & $\begin{array}{l}.877 * * \\
.000\end{array}$ & 1 & 24.91 & 13.33 \\
\hline
\end{tabular}

\section{Testing of Hypotheses 13 - 22 (System factors)}

Ten system factors were tested in this study. Results in Table 3 revealed that there were significant relationships between availability of full-text articles, $\left(\beta=.78^{* *}, \mathrm{P}(.000)<.05\right)$, quality of content, $(\beta=.717 * *, \mathrm{P}(.000)<.05)$, currency of content, $(\beta=.729 * *$, $\mathrm{P}(.000)<.05)$, free download of articles, $(\beta=.704 * *, P(.000)<.05)$, local journal content, $\left(\beta=.753^{* *}, \mathrm{P}(.000)<.05\right)$, database design features, $\left(\beta=.750^{* *}, \mathrm{P}(.000)<.05\right)$, quick access to journal articles, $\left(\beta=.730^{* *}, \mathrm{P}(.000)<.05\right)$, databases compatibility, $\left(\beta=.703^{* *}, \mathrm{P}(.000)<.05\right)$, perceived usefulness, $\left(\beta=.714^{* *}, \mathrm{P}\right.$ $(.000)<.05)$, perceived ease of use, $\left(\beta=.734^{* *}, \mathrm{P}(.000)<.05\right)$ and utilisation of Research4Life databases. The hypotheses were therefore accepted. The result also showed a strong correlation between the system factors and utilisation of Research4Life databases as their correlation values range from 0.704 to 0.753 . It therefore means that all ten system factors were significant factors influencing utilisation of Research4Life databases in NARIs. 
Table-3: Correlation matrix showing the significant relationships between system factors and utilisation of Research4Life databases by NARIs scientists in Nigeria

\begin{tabular}{|c|c|c|c|c|c|c|c|c|c|c|c|c|c|}
\hline & 1 & 2 & 3 & 4 & 5 & 6 & 7 & 8 & 9 & 10 & 11 & Mean & S.D \\
\hline 1 & 1 & & & & & & & & & & & 34.16 & 19.07 \\
\hline 2 & $\begin{array}{l}.748 * * \\
.000\end{array}$ & 1 & & & & & & & & & & 24.91 & 13.56 \\
\hline 3 & $\begin{array}{l}.717 * * \\
.000\end{array}$ & $\begin{array}{l}.869 * * \\
.000\end{array}$ & 1 & & & & & & & & & 25.60 & 14.65 \\
\hline 4 & $\begin{array}{l}.729 * * \\
.000\end{array}$ & $\begin{array}{l}.864 * * \\
.000\end{array}$ & $\begin{array}{l}.920 * * \\
.000\end{array}$ & 1 & & & & & & & & 25.17 & 14.54 \\
\hline 5 & $\begin{array}{l}.704 * * \\
.000\end{array}$ & $\begin{array}{l}.819 * * \\
.000\end{array}$ & $\begin{array}{l}.834 * * \\
.000\end{array}$ & $\begin{array}{l}.870 * * \\
.000\end{array}$ & 1 & & & & & & & 24.68 & 12.68 \\
\hline 6 & $\begin{array}{l}.753 * * \\
.000\end{array}$ & $\begin{array}{l}.870 * * \\
.000\end{array}$ & $\begin{array}{l}.847 * * \\
.000\end{array}$ & $\begin{array}{l}.868 * * \\
.000\end{array}$ & $\begin{array}{l}.846^{* *} \\
.000\end{array}$ & 1 & & & & & & 24.62 & 13.49 \\
\hline 7 & $\begin{array}{l}.750 * * \\
.000\end{array}$ & $\begin{array}{l}.877 * * \\
.000\end{array}$ & $\begin{array}{l}.872 * * \\
.000\end{array}$ & $\begin{array}{l}.870 * * \\
.000\end{array}$ & $\begin{array}{l}.822 * * \\
.000\end{array}$ & $\begin{array}{l}.890 * * \\
.000\end{array}$ & 1 & & & & & 31.08 & 17.49 \\
\hline 8 & $\begin{array}{l}.730 * * \\
.000\end{array}$ & $\begin{array}{l}.879 * * \\
.000\end{array}$ & $\begin{array}{l}.851^{* *} \\
.000\end{array}$ & $\begin{array}{l}.850 * * \\
.000\end{array}$ & $\begin{array}{l}.819^{* * *} \\
.000\end{array}$ & $\begin{array}{l}.857^{* *} \\
.000\end{array}$ & $\begin{array}{l}.916^{* *} \\
.000\end{array}$ & 1 & & & & 24.31 & 13.85 \\
\hline 9 & $\begin{array}{l}.703 * * \\
.000 \\
\end{array}$ & $\begin{array}{l}.847 * * \\
.000\end{array}$ & $\begin{array}{l}.837 * * \\
.000\end{array}$ & $\begin{array}{l}.831 * * \\
.000 \\
\end{array}$ & $\begin{array}{l}.793 * * \\
.000 \\
\end{array}$ & $\begin{array}{l}.828^{* * *} \\
.000\end{array}$ & $\begin{array}{l}.834 * * \\
.000 \\
\end{array}$ & $\begin{array}{l}.869 * * \\
.000\end{array}$ & 1 & & & 25.91 & 14.82 \\
\hline 10 & $\begin{array}{l}.714 * * \\
.000\end{array}$ & $\begin{array}{l}.848^{* *} \\
.000\end{array}$ & $\begin{array}{l}.842 * * \\
.000\end{array}$ & $\begin{array}{l}.826^{* * *} \\
.000\end{array}$ & $\begin{array}{l}.780 * * \\
.000\end{array}$ & $\begin{array}{l}.831^{* * *} \\
.000\end{array}$ & $\begin{array}{l}.837 * * \\
.000\end{array}$ & $\begin{array}{l}.857 * * \\
.000\end{array}$ & $\begin{array}{l}.938 * * \\
.000\end{array}$ & 1 & & 33.65 & 19.00 \\
\hline 11 & $\begin{array}{l}.734 * * \\
.000\end{array}$ & $\begin{array}{l}.828 * * \\
.000\end{array}$ & $\begin{array}{l}.810^{* *} \\
.000\end{array}$ & $\begin{array}{l}.812 * * \\
.000\end{array}$ & $\begin{array}{l}.785^{* *} \\
.000\end{array}$ & $\begin{array}{l}.802 * * \\
.000\end{array}$ & $\begin{array}{l}.814 * * \\
.000\end{array}$ & $\begin{array}{l}.838 * * \\
.000\end{array}$ & $\begin{array}{l}.899 * * \\
.000\end{array}$ & $\begin{array}{l}.922 \\
* * \\
.000\end{array}$ & 1 & 31.03 & 18.70 \\
\hline
\end{tabular}

Key: 1. Utilisation of Research4Life databases; 2. Availability of full-text Articles; 3. Quality of content; 4. Currency of content; 5. Free download of articles; 6. Local journal content; 7. Database design features; 8. Quick access to journal articles; 9. Databases compatibility; 10. Perceived usefulness; and 11. Perceived ease of use

Hypothesis 23: Individual, institutional and system factors will jointly influence utilisation of Research4Life databases by scientists in NARIs in Nigeria.

To complement the earlier results, multiple regression analysis was performed on the mean scores of individual, institutional and system factors, and utilisation of Research4Life databases. Result in Table 4 showed that the joint effect of individual, institutional and system factors (intention to use, task at hand, computer anxiety, prior ICT experience, ICT searching skills and computer/Internet self-efficacy, accessibility of databases, availability of password, fast Internet access, adequate training, adequate ICT infrastructure and help/technical support services, availability of full text articles, quality of content, currency of content, free download of articles, local journal content, database design features, quick access to journal articles, databases compatibility, perceived usefulness and perceived ease of use) on utilisation of Research4Life databases was significant. The hypothesis was therefore accepted.

Table-4: Correlation of individual, institutional and system factors and utilisation of Research4Life databases by NARIs scientists in Nigeria

\begin{tabular}{|c|c|c|c|c|c|c|}
\hline $\mathbf{r}$ & \multicolumn{3}{|l|}{ r Square } & $\begin{array}{l}\text { Adjusted R } \\
\text { Square } \\
\end{array}$ & \multicolumn{2}{|c|}{$\begin{array}{l}\text { Std. Error of the } \\
\text { Estimate }\end{array}$} \\
\hline .817 & \multicolumn{2}{|l|}{.668} & & .652 & \multicolumn{2}{|c|}{11.2475} \\
\hline \multicolumn{7}{|c|}{$\mathrm{A} N \mathrm{O} \mathrm{OA}$} \\
\hline Model & $\begin{array}{l}\text { Sum of } \\
\text { Squares }\end{array}$ & DF & $\begin{array}{l}\text { Mean } \\
\text { Square }\end{array}$ & $\mathrm{F}$ & Sig. & Remark \\
\hline $\begin{array}{l}\text { Regression } \\
\text { Residual } \\
\text { Total }\end{array}$ & $\begin{array}{l}120449.6 \\
59963.486 \\
180413.1\end{array}$ & $\begin{array}{l}22 \\
474 \\
496\end{array}$ & $\begin{array}{l}5474.984 \\
126.505\end{array}$ & 43.279 & .000 & Sig. \\
\hline
\end{tabular}

The result also shows a coefficient of multiple correlation $\left(\mathrm{R}=.817\right.$ and a multiple $\mathrm{R}^{2}$ of .668 . This means that $66.8 \%$ of the variance was accounted for by the predictor variables when taken together. The significance of the composite contribution was tested at $\mathrm{P}<.05$. The table also shows that the analysis .of variance (ANOVA) for the regression yielded a F-ratio of 43.279 (significant at 0.05 level). This implies that the joint contribution of the independent variables to the dependent variable was significant and that other variables not included in this model may have accounted for the remaining variance. 


\section{DisCUSSION OF FINDINGS}

The study adapted four models to develop the URDM to investigate factors influencing utilisation of Research4Life databases in NARIs in Nigeria. The model was validated based on its variance-covariance matrices. Statistical analysis revealed that hypotheses 1-22 were significant meaning that the factors influenced utilisation of Research4Life databases and therefore can adequately be applied to investigate individual, institutional and system factors influencing utilisation of Research4Life databases in Nigeria. Overall, the model accounted for $67 \%$ variance in the factors influencing utilisation of Research4Life databases among NARIs scientists in Nigeria. Similar findings by Wong, Osman, Goh, and Rahmat [55] indicated that TAM accounted for $37 \%$ of the variance in intention to use technology by student teachers in Malaysia. Combining four models in this study has enhanced the capacity to explore a broad spectrum of factors resulting in $67 \%$ variance obtained in this study. Therefore, URDM is adequate for investigating factors influencing utilisation of Research4Life databases in Nigeria. Figure 1 shows a schematic view of the resulting model based on the findings of this study. This model can be used to achieve $67 \%$ utilisation level of Research4Life databases in NARIs.

\begin{tabular}{|c|c|c|}
\hline Independent variables & & Dependent variables \\
\hline \multicolumn{2}{|l|}{ Individual factors } & \\
\hline 1. Intention to use & $\mathrm{Hl}$ & \\
\hline 2. Task at hand & $\mathrm{H} 2$ & \\
\hline 3. Computer anxiety & H3 & \\
\hline 4. Prior IT experience & $\mathrm{H} 4$ & \\
\hline 5.ICT searching skills & H5 & \\
\hline 6. Computer/Internet self-efficacy & H6 & Utilisation of \\
\hline \multicolumn{2}{|l|}{ Institutional factors } & Databases \\
\hline 1.Databases accessibility & H7 & (HINARI,AGORA \\
\hline 2. Availability of password & H8 & \& OARE) \\
\hline 3. Fast Internet access & H9 & \\
\hline 4. Adequate training & Hl0 & - Frequency of use \\
\hline 5. Adequate ICT infrastructure & Hll & \\
\hline 6. Help/technical support services & $\mathrm{H12}$ & - Time spent \\
\hline \multicolumn{2}{|l|}{ System factors } & - Intensity of use \\
\hline 1. Availability of full text articles & $\mathrm{Hl3}$ & No ofdom tond \\
\hline 2. Quality of databases content & $\mathrm{Hl4}$ & - No of downloads \\
\hline 3. Currency of databases content & Hls & \\
\hline 4. Free download of joumal articles & H16 & \\
\hline 5. Availability of local journal content & $\mathrm{Hl7}$ & \\
\hline 6. Database design features & H18 & \\
\hline 7. Quick access to journal articles & H19 & \\
\hline 8. Database compatibility & $\mathrm{H} 20$ & \\
\hline 9. Perceived system eas e of use & $\mathrm{H} 2 \mathrm{l}$ & \\
\hline 10. Perceived sys tem usefulhess & $\mathrm{H} 22$ & \\
\hline
\end{tabular}

Fig-1: Utilisation of Research4Life Database Model (URDM) (Constructed by the researcher)

The results of hypothesis 23 revealed that there was a good positive significant combined influence of individual, institutional and system factors on utilisation of Research4Life databases by scientists in NARIs in Nigeria. This result implied that for Research4Life databases to be adequately utilised in NARIs, individual, institutional and system factors should be considered holistically. If any of these factors is neglected the desired result may not be achieved. This finding corroborates the findings of Ogbomo [56] that computer skills (individual), institutional factors and usability (system) factors individually and collectively correlated with utilisation of Research4Life databases. Osubor and Chiemeke [57] also found strong and positive relationship of individual, institutional, technological factors (perceived usability, system quality, service quality, perceived value, facilitation condition, effort expectancy, perceived usefulness, perceived ease of use, social influence, information quality and self-efficacy) and stakeholders intention to adopt e-learning innovations in teaching-learning activities in 10 federal universities in Nigeria.

In Africa, Miller and Khera [39] found that individual, institutional and system factors - relevance, trust and ease of access, social norm, domain knowledge, visibility, and self-efficacy were major independent constituent drivers of the TEEAL system by agricultural researchers in Kenya and Peru. In Uganda, Alison, Kiyingi and Baziraake [26] revealed that utilisation of e-resources by graduate students, faculty and researchers was influenced by human and institutional factors in three universities. In Zimbabwe, Malapela and Jager [42] posited that academics in agriculture 
depend on current articles in Research4Life databases for their own research thus influencing usage of the databases. At Laurentian University, Lamothe [58] found that free download of full-text articles influence the rate of utilisation of ejournal collection in their library. In Indian, Rajan and Baral [59] showed that individual, organisational and technological factors (computer self-efficacy, organisational support, training, and compatibility) have positive influence on usage of Entreprise Resource Planning. Gelana [60] concluded that technology, organisational, and individual factors facilitate the use of Nursing Information System (NIS) in residential aged home care.

\section{CONCLUSION}

This study has empirically developed and validated the Utilisation of Research4life Database Model for investigating factors influencing utilisation of the Research4life databases in NARIs in Nigeria. All the 22 factors in the model were found to contribute significantly in predicting utilisation of Research4life databases individually and collectively. Librarians and other stakeholder interested in agricultural research can adopt or adapt this model for future research in predicting acceptance and utilisation of Research4life databases in Nigeria.

\section{REFERENCES}

1. Research4Life. (2020). About Research4Life. Retrieved June 24, 2020, from http://www. research4Life.org/about/

2. Lwoga, E.T., Chimwaza, G., Aronson, B., \& Vent, O. (2007). Building science information fluency in African Universities: how libraries and researchers are benefiting from improved access to science scholarship. World Library and Information Congress: $73^{\text {rd }}$ IFLA General Conference and Council, 19-23 August, Durban, South Africa. Retrieved May 9, 2011, fromhttp://www.ifla.org/iv/ifla73/index.htm

3. Information Training and Outreach Centre for Africa. (2008). HINARI exercises manual. AGORA/HINARI/OARE training of trainer workshop - HINARI, 3 - 7 November, 2008. MICHAEL Okpara University of Agriculture, Umudike: ITOCA, 2008.

4. Davis, F. D. (1986). A technology acceptance model for empirical testing new end-user information systems: theory and results. Doctoral Dissertation, MIT Sloan School of Management, Cambridge, MA.

5. _ Morris, M.G., Davis, G.B., \& Davis, F.D. (2003). User acceptance of information technology: towards a unified view. Management Information Systems Quarterly, 27(3), 425-478.

6. Dulle, F.W., \& Minish-Majanja, M.K. (2011). The suitability of the Unified theory of acceptance and use of technology (UTAUT) model on open access adoption studies. Information Development 27(1), 32-45.

7. Angello, C. (2010). The awareness and use of electronic information sources among livestock researchers in Tanzania. Journal of Information Literacy, 4(2), 6-22.

8. Igbeka, J.U., \& Atinmo, M.I. (2001). The influence of the work place on the information seeking behaviour and information utilisation of Nigerian agricultural engineers. Nigerian Libraries, 35(1), 1-14.

9. Wang, P., \& Wu, L. (2011). Research use of the Internet ICT by Faculty: an interdisciplinary and cross cultural comparison. Retrieved May 27, 2011, from www.cci.utk.edu/files/u14/wang pdf.

10. Shih, Y., \& Huang, S. (2009). The actual usage of ERP systems: an extended technology acceptance perspective. Journal of Research and Practice in Information Technology, 41(3), 263-276.

11. Venkatesh, V. \& Bala, H. (2008). Technology acceptance model 3 and a research agenda on interventions. Decision Science, 39(2), 273-315.

12. Nov, O., \& Ye, C. (2008). Users' personality and perceived ease of use of digital libraries: the case of resistance to change. Journal of the American Society of Information science and Technology, 59(5), 845-851.

13. Crespo, A.H., Sanchez, M.M.G., \& Bosque, I.R. (2013). Influence of users' perceived compatibility and their prior experience on B2C e-commerce acceptance. In: Electronic Business and Marketing. Edited by T. Matsuo and R. Colomo-Palaclos.Studies in Computational Intelligence - 484, 103 - 123.

14. Lee, C., \& Coughlin, J.F. (2015). Generational differences in adoption and use of information and communication technology. Proceedings of the Human Factors and Ergonomics Society Annual Meeting, 59(1), 892-896.

15. Abramson, J., Dawson, M., \& Stevens, J. (2015). An examination of the prior use of e-learning within an extended technology acceptance model and the factors that influence the behavioural intention of users to use m-learning. SAGE Open, 1-9. DOI: 10.1177/2158244015621114.

16. Adeyinka, T. (2009). Attitudinal correlates of some selected Nigerian librarians towards the use of ICT. International Journal of Information Science \& Management, 7(1), 15-30.

17. Muinde, F.N.N., \& Gorman, G.E. (2009). Barriers to open access to scientific information in Kenya, with particular reference to agricultural information. World Library and Information Congress: $75^{\text {th }}$ IFLA General Conference and Council, 23 - 27 August, 2009, Milan, Italy

18. Parker, K. (2009). Further reflection of open access. Bulletin of World health Organisation, 87: 732. Doi: 10.2471/BLT.09.070946.

19. Akinbobola, O.I., \& Adeleke, A.A. (2013). The influence of user efficacy and expectation on actual system use. Interdisciplinary Journal of Information, Knowledge and Management, 8, 43-57. 
20. Odede, I. (2015). Undergraduates' computer skills and the use of online information resources: a case study of library and information science students of Delta State University, Nigeria. International Research: Journal of Library \& Information Science, 5(4), 770-782.

21. Nwobu, B., Oyewole, O., \& Apotiade, J.K. (2016). Computer self-efficacy as correlate of Online Public Access Catalogue (OPAC) use: a case study. Information Impact, 7(2), 15-26.

22. Park, S.Y. (2009). An analysis of the technology acceptance model in understanding university students' behavioural intention to use e-learning. Educational Technology and Society, 12(3), 150-162. (2013). Report on post workshop surveys for the ITOCA ToT workshops held in seven SubSaharan countries. South Africa: ITOCA.

24. Uzuegbu, C.P., \& McAlbert, F.U. (2012). Digital librarians and the challenges of open access to knowledge; the Michael Okpara University of Agriculture (MOUAU) library experience. Library Philosophy and Practice 2012. Retrieved Mar. 27, 2014, from http://unllib.unl.edu.LPP/

25. Salaam, M.O. (2007). Options for access to journals, print, CD-ROM, On-line in a Nigerian agricultural University library. Samaru Journal of Information Studies, 7(2), 24-27.

26. Alison, K.A., Kiyingi, G.W., \& Baziraake, B.B. (2012). Factors affecting utilisation of electronic health information resources in universities in Uganda. Annals of Library and Information Studies, 59, 90-99.

27. Rhoe, V. Oboh, V., \& Shelton, P. (2010). The role of libraries in supporting agricultural policy research-evidence from selected university and research institute libraries in Nigeria. NSSP Background paper No. 0014.

28. Ogunjobi, T.E., \& Fagbami, O.O. (2012). Use of the Internet by researchers in agricultural research institutes in Ibadan, Oyo State. International Journal of Library and Information Science, 4(4), 52-56. Benin City: ITOCA, 2014

(2014). Research4Life and TEEAL training manual. 15 -17 July, 2014. University of Benin,

30. Lakan, E.L. (2008). Availability and utilization of electronic information databases by staff of the agricultural complex, Ahmadu Bello University, Zaria. Samaru Journal of Information Study, 8(1), 44-53.

31. Chimwaza, G., \& Chimalizeni, M. (2011). Capacity building in library services: influencing innovation and competitiveness. Economic Commision for Africa: Second Session of the Committee on Development of Information, Science and Technology (CODIST-II), 2 - 5 May, 2011. 1-9.

32. Mtega, W.P., Dulle, F., Malekani, A.W. \& Chailla, A. (2014). The usage of e-resources among agricultural researchers and extension staff in Tanzania. Library and Information Research, 38(119), 47-66.

33. Chang, P.V. (2004). The validity of extended technology Acceptance Model (TAM) for predicting Intranet/portal usage. A Master paper submitted to the faculty of the School of Information and Library Science, University of North Carolina, Chapel Hil. 36p.

34. Seymour, L., Allen, G., \& Duma, N. (2008). The i-mpact of student diversity on student portal usage. Proceedings cultural attitudes towards communication and technology, Murdoch University, Australia, F. Sudweeks, H. Hrachovec and C. Ess. Eds. 484-498.

35. Abbad, M.M., Morris, D., \& de Nahlik, C. (2009). Looking under the bonnet: factors affecting students' adoption of e-learning systems in Jordan. The International Review of Research in Open and Distance Learning, 10(2), 1-25.

36. Wood, E. (2007). What is HINARI. Bioscience Education Journal 10. Retrieved May 18, 2011, from www.bioscience.heacademy.ac.uk/journal/vol 10/beej-10-R1.pdf.

37. Gaible, E., Gedye, R., Ochs, M., Parker, K., \& Rudgard, S. (2011). Research4Life: bringing academic and professional peer-reviewed content to developing countries through public-private partnership. Retrieved Mar. 4, 2016, from http://conference.ifla.org/ifla77.

38. Shabi, I.N., Shabi, O.M., Akewukereke, M.A., \& Udofia, E.P. (2011). Physician utilisation of Internet medical database at the tertiary health institutions in Osun State, Nigeria. Health Information Library Journal, 28(4), 313320.

39. Miller, J., \& Khera, O. (2010). Digital library adoption and the Technology Acceptance Mode: a cross-country analysis. The Electronic Journal on Information Systems in Developing Countries, 40(6), 1-19.

40. Tao, D. (2009). Intention to use and actual use of electronic information resources: further exploring technology acceptance model AMIA 2009 Symposium Proceeding, 629-633.

41. Paj, F., \& Huang, K. (2011). Applying the Technology Acceptance Model to the introduction of healthcare information systems. Technological Forecasting and Social Change, 78(4), 650-660.

42. Malapela, T., \& Jager, K. (2015). Using an electronic journal availability study to measure access to electronic journals by academic and researchers in the Faculty of Agriculture at the University of Zimbabwe. Library and Information Research, 39(120), 29-42.

43. Davis, P.M., \& Walters, W.H. (2011). The impact of free access to the scientific literature: a review of recent research. Journal of Medical Library Association, 99(3), 208-217.

44. Bringula, R.P., \& Basa, S. (2011). Factors affecting faculty web portal usability. Educational Technology and Society, 14(4), 253-265.

45. Ahn, T., Ryu, S., \& Han, I. (2007). The impact of web quality and playfulness on user acceptance of online retailing. Information and Management, 44(3), 263-275. 
46. Thanuskodi, S. (2010). Use of Internet and electronic resources for agricultural science information: a case study. The Social Science, 5(4), 364-367.

47. Chau, P.Y.K. \& Hu, P.J. (2001). Information technology acceptance by individual professionals: a model comparison approach. Decision Science, 32(4), 699-719.

48. Wu, J., \& Wang, S. (2005). What drives mobile commerce? An empirical evaluation of the revised technology acceptance model. Information and Management, 42, 719-729.

49. Brown, I.T.J. (2002). Individual and technological factors affecting perceived ease of use of web-based learning technologies in a developing country. The Electronic Journal on Information Systems in Developing Countries, 9(5), $1-15$.

50. Korobili, S., Tilikidou, I., \& Delistavrou, A. (2006). Factors that influence the use of library resources by faculty members. Library Review, 55(2), 91-105.

51. Rogers, E.M. (1995). Diffusion of Innovations, 4th ed., Free Press, New York.

52. DePietro, R., Wiarda, E., \& Fleischer, M. (1990). The context of change: organization, technology and environment. In: Tornatzky, L.G. and Fleischer, M. (eds.). The processes of technological innovation. Lexington Books: Lexington, MA. 151-175.

53. Hameed, M.A., Counsell, S., \& Swift, S. (2012). A conceptual model for the process of IT innovation adoption in organisations. Journal of Engineering and Technology Management, 29(3), 358-390.

54. Stieninger, M. \& Nedbal, D. (2014). Diffusion and acceptance of cloud computing in SMs: towards a valance model of relevant factors. Fourth Hawaii International Conference on System Science. DOI: 10.1109/HICSS.2014.410. $3307 / 3316$.

55. Wong, K, Osman, R., Goh, P.S.C., \& Rahmat, M.K. (2013). Understanding student teachers' behaviouiral intention to use technology: Technology Acceptance Model (TAM) validation and testing. International Journal of Instruction, 6(1), 89-102.

56. Ogbomo, M.O. (2013). Computer skills, institutional factors, usefulness and usability as predictors of lecturers' utilisation of scholarly electronic publications for research in federal universities in Nigeria. Ph.D. project. Department of Library, Archival and Information Studies, University of Ibadan, Nigeria.142p.

57. Osubor, V.O., \& Chiemeke, S.C. (2015). The impacts of information culture on e-learning innovation adoption in learning institutions in Nigeria. African Journal of Computing \& ICT, 8(1), 17-26.

58. Lamothe, A.R. (2012). Factors influencing usage of an electronic journal collection at a medium-size university: an eleven-year study. Partnership, 7(1), 1-12.

59. Rajan, C.A., \& Baral, R. (2015). Adoption of ERP system: an empirical study of factors influencing the usage of ERP and its impact on end user. IIMB Management Review, 27, 105-117.

60. Galani, M. (2015). Factors affecting nursing staff use of nursing information systems in residential aged care homes. Doctor of Philosophy Thesis, School of Information Systems \& Technology - Faculty of Engineering \& Information Sciences, University of Wollongong, 2015. Retrieved June 13, 2016, from http://ro.uow.edu.au/theses/4422. 